\title{
Climate change impacts and responses in the Philippines: water resources
}

\author{
Aida M. J ose, Nathaniel A. Cruz* \\ Climatology and Agrometeorology Branch (CAB), Philippine A tmospheric, Geophysical and Astronomical Services \\ Administration (PAG ASA), 1424 Quezon Ave., Quezon City, Philippines
}

\begin{abstract}
The Philippines, like many of the world's poor countries, will be among the most vulnerable to the impacts of climate change because of its limited resources. As shown by previous studies, occurrences of extreme climatic events like droughts and floods have serious negative implications for major water reservoirs in the country. A preliminary and limited assessment of the country's water resources was undertaken through the application of general circulation model (GCM) results and climate change scenarios that incorporate incremental changes in temperature and rainfall and the use of a hydrological model to simulate the future runoff-rainfall relationship. Results showed that changes in rainfall and temperature in the future will be critical to future inflow in the Angat reservoir and Lake Lanao, with rainfall variability having a greater impact than temperature variability. In the Angat reservoir, runoff is likely to decrease in the future and be insufficient to meet future demands for water. Lake Lanao is also expected to have a decrease in runoff in the future. With the expected vulnerability of the country's water resources to global warming, possible measures to cope with future problems facing the country's water resources are identified.
\end{abstract}

KEY WORDS: Water resources $\cdot \mathrm{GCMS} \cdot \mathrm{CCCM} \cdot \mathrm{UKMO} \cdot \mathrm{GFDL} \cdot$ WatBal $\cdot$ Angat reservoir $\cdot$ Lake Lanao

\section{INTRODUCTION}

The Philippine archipelago is composed of 7100 islands, clustered in 3 major island groups - namely, Luzon, Visayas, and Mindanao-with a total land area of $300000 \mathrm{~km}^{2}$. The country's climate is influenced by large-scale atmospheric phenomena that bring in substantial amounts of rains almost all year round. However, due to the uneven distribution of rain with respect to time and space and the occurrences of extreme events such as floods and droughts, the country's water resources have in the past experienced imbalances in supply and demand ( ose et al. 1993).

Global warming is expected to occur due to increased carbon dioxide concentration in the atmosphere. Global surface temperature will increase by at

\footnotetext{
*Addressee for correspondence.

E-mail: natcruz@philonline.com.ph
}

least $2.0^{\circ} \mathrm{C}$ by the next century (IPCC 1996a). Significant changes in the earth's climatic system, particularly an alteration of rainfall and temperature in both time and space, is expected. During the past few decades, extreme climatic events have adversely affected the Philippine economy. El Niño-related droughts affected not only the water sector but also other sectors such as agriculture, health, and environment (J ose 1992). The EI Niño-related drought of 1982-83, for example, has affected thousands of agricultural areas in the Philippines, including multipurpose reservoirs, where very low water levels were recorded.

The objective of this paper is to be able to assess the vulnerability of selected major multipurpose reservoirs of the country to climate change, as represented by results of selected general circulation models (GCMs) and scenarios incorporating incremental changes. Ultimately, possible adaptation measures to cope with potential impacts of climate change are identified. 


\section{METHODOLOGY}

2.1. Study areas. There are currently 6 major reservoirs in the country-namely, Ambuklao, Magat, Binga, Pantabangan, Angat, and Lake Lanao (Fig. 1). For the vulnerability assessment, 2 of these reservoirs, Angat and Lake Lanao, were chosen as pilot areas in view of their socioeconomic importance.

2.1.1. Angat Reservoir: The Angat multipurpose reservoir, located on the island of Luzon, is the main municipal water source for M etro M anila, which is the center of major economic, social, and political activities in the country. It also supplies irrigation water, serves as flood control for areas downstream, and contributes to power generation to meet Luzon's power requirement. The Angat multipurpose reservoir has an effective capacity of $640 \mathrm{M} \mathrm{m}^{3}$ and regulates an average annual inflow of $1700 \mathrm{M} \mathrm{m}^{3}$. The Angat river basin has a total drainage area of $936 \mathrm{~km}^{2}$, while the upper basin, which covers the area from the farthest watershed divide down to Angat Dam, is $568 \mathrm{~km}^{2}$ (Rosacay 1989).

The Angat Maasim River Irrigation System (AM RIS) of the National Irrigation Administration (NIA) derives water mainly from Angat Dam, which irrigates a total service area of 31484 ha (NIA report to Angat Study Team). The average irrigated area during the dry season (J une to November) is 26613 ha, while during the wet season (November to A pril) the average irrigated area is about 22100 ha. For domestic requirements of $M$ etro $M$ anila and some adjoining towns, the Metro-

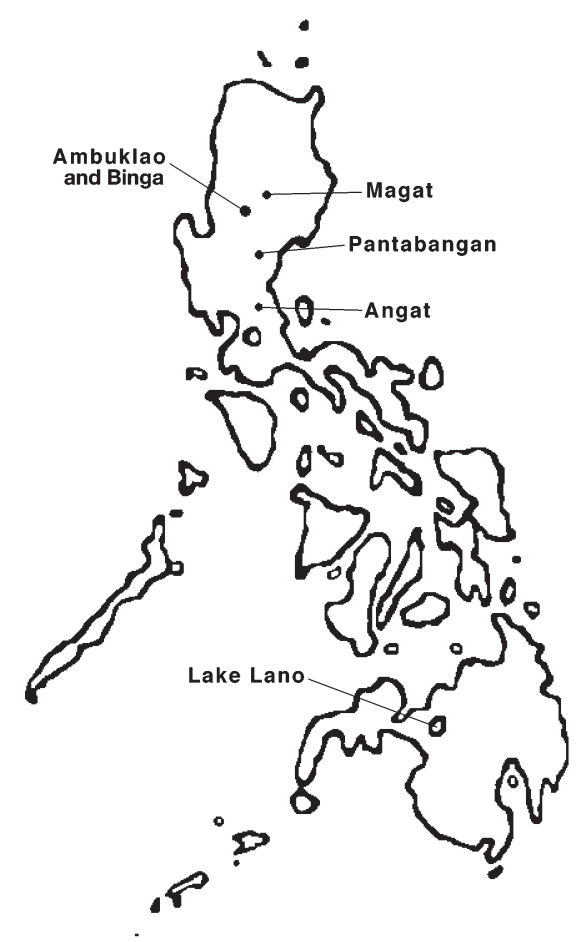

Fig. 1. Major water reservoirs in the Philippines politan Waterworks and Sewerage System (MWSS) derives almost $90 \%$ of its feed water from the Angat water reservoir (the remaining $10 \%$ is from underground sources). The MWSS, due to increasing demand, has had to seek an additional water right (from 22 to $37 \mathrm{~m}^{3} \mathrm{~s}^{-1}$ ). For power generation, the National Power Corporation (NPC) has operated and maintained the Angat Dam since its construction in 1968. The water released for irrigation and domestic uses is first routed through the reservoir's hydroelectric turbine generators.

2.1.2. Lake Lanao: Lake Lanao is the second largest lake of the country, with a volume of about $21500 \mathrm{M} \mathrm{m}^{3}$ and a total annual average inflow of $3302 \mathrm{M} \mathrm{m}^{3}$ from its 6 major tributaries. It has an approximate watershed area of $1680 \mathrm{~km}^{2}$ and is the main source of hydroelectric power of Mindanao Island (NPC-Iligan 1997).

The Lake Lanao-Agus River complex is of paramount importance to the economy of the country in general and the Mindanao Region in particular because, at present, more than $75 \%$ of the total power needs of the region's industrialization program emanates from the Agus hydropower plants. The prolonged drought of 1992 forced the NPC to curtail power on the entire island for 10 to $15 \mathrm{~h}$ daily. This power shortage caused economic losses of several billions of pesos on unrealized revenues and loss of economic opportunities (NPC report).

2.1.3. Data sources: In total, $27 \mathrm{yr}$ of hydroclimatological data (1968 to 1994) for the Angat dam analysis were provided by PAGASA (climatological) and the NPC (runoff). Runoff data for 47 yr (1948 to 1994) were extracted from NPC archives and were utilized in the Lake Lanao analysis. Daily rainfall data were taken from 5 hydrologic stations ( 4 are operated by NPC and 1 by PAGASA) covering the period from 1970 to 1994.

\subsection{Scenarios used in vulnerability assessment}

2.2.1. GCM s: Predictions from GCM s based on doubled $\mathrm{CO}_{2}$ emissions were used in this study as the basis for climate change scenarios. The National Center for A tmospheric Research (NCAR), through the US Country Studies Program, has provided results from several GCMs that have simulated the effect of $\mathrm{CO}_{2}$ doubling on temperature, rainfall, and other meteorological parameters. Three models were chosen to represent future values of rainfall and precipitation under a double $\mathrm{CO}_{2}$ scenario (J ose et al. 1996). The 3 models selected were the Canadian Climate Center Model (CCCM) (Boer et al. 1992), the United Kingdom Meteorological Office (UKMO) model (Wilson \& Mitchell 1987), and the Geophysical Fluid Dynamics Laboratory (GFDL) model (M anabe \& Wetherald 1987). 
Table 1. Rainfall ratio and temperature change between current $\left(1 \times \mathrm{CO}_{2}\right)$ and $2 \times \mathrm{CO}_{2}$ as generated by $3 \mathrm{GCMs}$ for the Angat watershed

\begin{tabular}{|c|c|c|c|c|c|c|}
\hline \multirow{2}{*}{ Month } & \multicolumn{2}{|c|}{ СССM } & \multicolumn{2}{|c|}{ UKMO } & \multicolumn{2}{|c|}{ GFDL } \\
\hline & Rainfall ratio & Temp. change $\left({ }^{\circ} \mathrm{C}\right)$ & Rainfall ratio & Temp. change $\left({ }^{\circ} \mathrm{C}\right)$ & Rainfall ratio & Temp. change $\left({ }^{\circ} \mathrm{C}\right)$ \\
\hline Jan & 0.69 & 2.0 & 0.62 & 4.0 & 1.11 & 3.1 \\
\hline Feb & 1.11 & 2.1 & 2.0 & 3.7 & 1.35 & 2.4 \\
\hline Mar & 1.19 & 1.6 & 1.14 & 2.5 & 0.93 & 2.3 \\
\hline Apr & 0.75 & 1.9 & 0.53 & 3.5 & 1.09 & 2.3 \\
\hline May & 1.13 & 1.9 & 1.42 & 2.8 & 1.33 & 2.3 \\
\hline Jun & 0.87 & 2.0 & 0.86 & 2.7 & 0.77 & 2.3 \\
\hline J ul & 0.9 & 2.0 & 1.06 & 2.7 & 0.93 & 2.2 \\
\hline Aug & 1.03 & 2.2 & 1.26 & 2.4 & 1.08 & 2.0 \\
\hline Sep & 1.13 & 2.2 & 1.45 & 2.6 & 1.8 & 2.4 \\
\hline Oct & 1.03 & 2.3 & 0.92 & 2.4 & 0.88 & 2.6 \\
\hline Nov & 0.7 & 2.2 & 0.69 & 3.4 & 1.35 & 2.4 \\
\hline Dec & 0.8 & 2.0 & 0.46 & 4.3 & 1.18 & 2.8 \\
\hline Annual & 0.94 & 2.0 & 1.03 & 3.1 & 1.15 & 2.4 \\
\hline
\end{tabular}

Table 2. Rainfall ratio and temperature change between current $\left(1 \times \mathrm{CO}_{2}\right)$ and $\left(2 \times \mathrm{CO}_{2}\right)$ as generated by 3 GCM s for the Lake Lanao watershed

\begin{tabular}{|lcccccc|}
\hline \multirow{2}{*}{ Month } & \multicolumn{2}{c}{ CCCM } & \multicolumn{2}{c}{ UKMO } & \multicolumn{2}{c|}{ GFD } \\
& Rainfall ratio & Temp. change $\left({ }^{\circ} \mathrm{C}\right)$ & Rainfall ratio & Temp. change $\left({ }^{\circ} \mathrm{C}\right)$ & Rainfall ratio & Temp. change $\left({ }^{\circ} \mathrm{C}\right)$ \\
\hline Jan & 0.74 & 1.94 & 0.88 & 2.52 & 1.34 & 2.41 \\
Feb & 0.81 & 1.85 & 2.39 & 2.46 & 1.76 & 2.31 \\
M ar & 0.75 & 1.74 & 1.43 & 1.73 & 1.09 & 2.06 \\
A pr & 0.85 & 1.74 & 1.61 & 2.02 & 0.78 & 1.88 \\
May & 0.99 & 1.82 & 1.33 & 2.6 & 1.59 & 2.01 \\
Jun & 0.81 & 1.91 & 1.2 & 2.46 & 1.37 & 2.37 \\
Jul & 1.10 & 2.04 & 0.91 & 3.04 & 0.87 & 2.38 \\
Aug & 1.10 & 2.14 & 0.67 & 3.76 & 1.19 & 2.25 \\
Sep & 1.08 & 2.25 & 0.57 & 3.52 & 1.18 & 2.23 \\
Oct & 0.88 & 2.31 & 1 & 2.69 & 1.43 & 2.47 \\
Nov & 1.02 & 2.09 & 0.81 & 2.27 & 1.35 & 2.54 \\
Dec & 1.23 & 2.02 & 0.95 & 2.55 & 1.08 & 2.53 \\
Annual & 0.94 & 1.98 & 1.14 & 2.63 & 1.25 & 2.29 \\
\hline
\end{tabular}

Table 1 shows the temperature changes and rainfall ratios between $1 \times \mathrm{CO}_{2}$ and $2 \times \mathrm{CO}_{2}$ generated by the 3 models for the Angat reservoir. Temperature changes from the 3 models show an increasing trend that is consistent with the expected warming. The UKMO model gave the highest increase in annual temperature $\left(3.1^{\circ} \mathrm{C}\right)$, while the CCCM model predicts an increase of $2.0^{\circ} \mathrm{C}$. The 3 models, however, predicted varying changes in annual rainfall. The UKMO and UKMO models both predict an annual increase of rainfall over Angat, while a slight decrease is to be expected based on the CCCM model.

For Lake Lanao, Table 2 shows the temperature change and rainfall ratio between $1 \times \mathrm{CO}_{2}$ and $2 \times \mathrm{CO}_{2}$ generated by the 3 models. The GFDL model predicted the highest increase in mean annual temperature $\left(2.3^{\circ} \mathrm{C}\right)$ compared with UKMO $\left(2.6^{\circ} \mathrm{C}\right)$ and $\mathrm{CCCM}$ $\left(2.0^{\circ} \mathrm{C}\right)$. For rainfall changes, the GFDL and UKMO models predict an increase in annual rainfall, 25 and $14 \%$, respectively, whereas a reduction in rainfall is given in the CCCM results $(6 \%)$.

2.2.2. Incremental change based scenarios: Aside from the simulation results of the different circulation models, climate change scenarios were created using incremental changes in temperature and precipitation. These scenarios were also developed because of their advantage in capturing a wide range of climatic variability.

The incremental change scenarios adopted are the baseline, $2^{\circ} \mathrm{C}$ increase in temperature with $10 \%$ increase in precipitation (T2P10), $2^{\circ} \mathrm{C}$ increase in temperature with $10 \%$ reduction in precipitation (T2P-10), $4^{\circ} \mathrm{C}$ increase in temperature with $10 \%$ increase in precipitation (T4P10), and $4^{\circ} \mathrm{C}$ increase in 
temperature with $10 \%$ reduction in precipitation (T4P-10).

2.3. Rainfall-runoff simulation. In assessing the vulnerability of the pilot areas to climate change, a hydrologic model, WatBal (Yates 1994), was used to determine a rainfall-runoff relationship. WatBal is a lumped conceptual model that has 2 main modeling components: one is the water balance component, and the other is the calculation of potential evapotranspiration using the Priestly-Taylor radiation method.

The model was calibrated for the Angat river basin by using $18 \mathrm{yr}$ of data (1968 to 1985), and validation was based on $8 \mathrm{yr}$ of data (1986 to 1993). For Lake Lanao, the first $16 \mathrm{yr}$ (1970 to 1985) were used for calibration, and the succeeding 9 yr (1986 to 1994) for validation.

2.4. Limitations of the study. This vulnerability study has been rendered less exhaustive than it might have been primarily due to data limitations. It should be noted that the vulnerability assessment should have been done on a national scale but was conducted in only 2 of several existing multipurpose reservoirs in the country.

In the case of Lake Lanao, data on baseline scenarios-such as population, gross national product, agriculture, and deforestation-are nil and, if available, need validation. For the Angat reservoir, there are also uncertainties in the long-term projections of demand due to unavailability of data. Long-term projections of the 3 concerned agencies extend only up to the year 2005.

Potential impacts of climate change as well as adaptation assessments for other subsectors-such as drainage, flood control, water quality, salinity control, fisheries, protection of aquatic life, and navigationhave not been assessed.

\section{RESULTS AND DISCUSSION}

\subsection{Future water demand}

Future requirements for domestic and industrial purposes are expected to increase remarkably until 2050

Table 3. Projected water demand $\left(\mathrm{M} \mathrm{m}^{3} \mathrm{yr}^{-1}\right)$ of the Metropolitan Waterworks and Sewerage System (M WSS) and the National Irrigation Administration (NIA)

\begin{tabular}{|c|c|c|c|c|c|}
\hline \multirow[t]{2}{*}{ Year } & \multicolumn{4}{|c|}{ MWSS } & \multirow{2}{*}{$\begin{array}{c}\mathrm{NIA} \\
\text { Irrigation }\end{array}$} \\
\hline & Industrial & Commercial & Domestic & Total & \\
\hline 1995 & 108 & 269 & 534 & 911 & 872 \\
\hline 2000 & 121 & 348 & 805 & 1274 & 872 \\
\hline 2025 & 210 & 1133 & 1219 & 2563 & 872 \\
\hline 2050 & 339 & 2600 & 1630 & 4567 & 872 \\
\hline
\end{tabular}

Table 4. Changes in annual precipitation, temperature and runoff for Angat water reservoir from 3 GCMs (based on $2 \times$ $\mathrm{CO}_{2}$ )

\begin{tabular}{|lccc|}
\hline GCM & Rainfall ratio & $\begin{array}{c}\text { Temp. change } \\
\left({ }^{\circ} \mathrm{C}\right)\end{array}$ & $\begin{array}{c}\text { Runoff change } \\
(\%)\end{array}$ \\
\hline CCCM & 0.94 & 2.0 & -12 \\
UKMO & 1.03 & 3.1 & 5 \\
GFDL & 1.15 & 2.4 & 32 \\
\hline
\end{tabular}

(MWSS report to Angat Study Team). Growth rate for domestic use is high owing to the expected rapid migration of people to M etro Manila and suburbs and accelerated industrialization (Table 3). For irrigation, however, it is projected to remain al most the same until 2050 (NIA 1997). These clearly show that, for the Angat reservoir, future domestic, commercial, and industrial needs would be the main problem for the water management agencies. It is to be noted, however, that these projections did not consider any effects of the expected global warming, which could lead to higher water demands.

A reliable supply from Lake Lanao to meet the demand of the Agus power plants is estimated to vary from $80 \mathrm{~m}^{3} \mathrm{~s}^{-1}$ in the dry season to $125 \mathrm{~m}^{3} \mathrm{~s}^{-1}$ in the wet season. Domestic demand is roughly calculated to reach $15 \mathrm{~m}^{3} \mathrm{~s}^{-1}$ by the year 2050 (NPC-Iligan 1997). Projections on demands for irrigation and other beneficial uses of Lake Lanao water could not be determined due to non-availability of data.

\subsection{C limate change scenarios from G C M s}

Table 4 shows the change in annual precipitation and temperature and the corresponding change in runoff based on the climate change scenarios generated by the $3 \mathrm{GCMs}$ for the Angat reservoir. UKMO and GFDL showed an increase in runoff of 5 and $32 \%$, respectively. The increase in runoff is attributable to an increase in precipitation predicted by the 2 models. GFDL has the highest percent change in runoff since it has a $15 \%$ positive change in precipitation coupled with only a $2.4^{\circ} \mathrm{C}$ change in temperature. The UKMO model predicted only a small increase in precipitation but predicted a warmer temperature with a $3.1^{\circ} \mathrm{C}$ change. The CCCM scenario gave a $12 \%$ annual runoff reduction based on a prediction of less annual rainfall and warmer temperature. Based on GFDL results, greater frequency of flooding could be expected in the future, while, in the CCCM sce- 
Table 5. Projected total water supply and demand $\left(I \times 10^{6} \mathrm{~d}^{-1}\right)$ for Angat Reservoir in the year 2050

\begin{tabular}{|lrrrr|}
\hline & Baseline & CCCM & GFDL & UKMO \\
\hline Total water supply & 5011 & 4409 & 5261 & 6614 \\
Total water demand & 15405 & 15405 & 15405 & 15405 \\
Deficit & 10394 & 10996 & 10144 & 8971 \\
\hline
\end{tabular}

Table 6. Changes in annual precipitation, temperature and runoff for Lake Lanao water reservoir from $3 \mathrm{GCM} \mathrm{s}$ (based on $\left.2 \times \mathrm{CO}_{2}\right)$

\begin{tabular}{|lccc|}
\hline GCM & Rainfall ratio & $\begin{array}{c}\text { Temp. change } \\
\left({ }^{\circ} \mathrm{C}\right)\end{array}$ & $\begin{array}{c}\text { Runoff change } \\
(\%)\end{array}$ \\
\hline CCCM & 0.95 & 2.0 & -2 \\
UKMO & 1.15 & 2.6 & -12 \\
GFDL & 1.25 & 2.3 & 7 \\
\hline
\end{tabular}

Table 7. Percent change in Angat water reservoir runoff based from incremental changes in precipitation $(P)$ and temperature $(T)$

\begin{tabular}{|cccccc|}
\hline & P0 & P10 & P20 & P-10 & P-20 \\
\hline T0 & 0 & 8 & 18 & -15 & -25 \\
T2 & -1 & 8 & 17 & -15 & -26 \\
T4 & -1 & 7 & 17 & -16 & -26 \\
\hline
\end{tabular}

Table 8. Percent change in Lake Lanao water reservoir runoff based from incremental changes in precipitation $(\mathrm{P})$ and temperature $(T)$

\begin{tabular}{|cccccc|}
\hline & P0 & P10 & P20 & P-10 & P-20 \\
\hline T0 & 0 & -1 & 4 & -2 & -17 \\
T2 & -2 & -1 & 3 & -2 & -18 \\
T4 & -1 & -2 & 1 & -3 & -19 \\
\hline
\end{tabular}

nario, decreased runoff, presumably because of frequent drought episodes, would mean more serious problems in water availability. Table 5 shows the projected total water demand and supply for Angat Reservoir in the year 2050. The baseline scenario (without climate change) shows that future supply will not be sufficient to meet future demand. Based on the 3 models, the same relationship remains under potential climate change. It should be emphasized, however, that the monthly distribution of rainfall is far more critical than the annual distribution because of the varying monthly demand by domestic and agricultural users.

For Lake Lanao, Table 6 shows the changes in the annual precipitation, temperature, and runoff from the
$3 \mathrm{GCM}$ s based on $2 \times \mathrm{CO}_{2}$. Decrease in runoff could be expected from the results of 2 models, CCCM and UKMO. Although an increase in annual rainfall is expected from the UKMO model, a negative change in annual runoff ( $12 \%$ ) is predicted. This could somehow be attributed to the large increase in temperature $\left(2.6^{\circ} \mathrm{C}\right)$. For the GFDL model, it predicts a $7 \%$ increase in runoff coupled with increases both in rainfall and temperature.

\subsection{Incremental climate change scenarios}

The 14 climate change scenarios using incremental changes and the corresponding changes in runoff for the Angat reservoir are shown in Table 7. The table indicates that runoff is more sensitive to variations in precipitation as compared with temperature. An increase of 10 or $20 \%$ precipitation would mean an increase in runoff by 8 or $18 \%$, respectively. If precipitation is reduced by 10 or $20 \%$, a reduction in runoff by 15 or $25 \%$, respectively, is to be expected. This suggests that runoff is more affected by a decrease in precipitation than by an increase in precipitation.

On the other hand, a $2^{\circ} \mathrm{C}$ increase in temperature would only lead to a $1 \%$ reduction in runoff. The scenarios with a $2^{\circ} \mathrm{C}$ change in temperature and a corresponding increase or decrease of $10 \%$ in precipitation likewise showed an $8 \%$ increase or $15 \%$ decrease in runoff, respectively.

For Lake Lanao, the 14 climate change scenarios using incremental changes are shown in Table 8 . The table also shows that, generally, runoff is much more sensitive to rainfall than temperature. With no change in temperature and a decrease in rainfall by 10 or $20 \%$, there is a corresponding decrease in runoff by 2 or $17 \%$, respectively. A $2^{\circ} \mathrm{C}$ increase in temperature and again a 10 or $20 \%$ decrease in rainfall would translate to a 2 or $18 \%$ decrease in runoff. Likewise, further increasing the temperature to $4^{\circ} \mathrm{C}$ with a 10 or $20 \%$ decrease in rainfall would result in a $3 \%$ or $19 \%$ decrease in runoff. Based on historical data, Lake Lanao has experienced significant decreases in runoff $(18 \%$ or more) due to decreased rainfall associated with ENSOrelated drought events. These results simply indicate that runoff is more sensitive to variations in precipitation as compared with variations in temperature.

Further studies should be done to investigate the effects of temperature increases as well as the effects of other meteorological variables on Angat Reservoir's and Lake Lanao's runoff since this vulnerability assessment assumes that, with the increase in temperature and rainfall, other meteorological parameters like relative humidity and wind, among others, remain constant. 
Aside from the expected climate change and its impacts on the water resources sector, there are still a number of external factors that could contribute to the modification of the water supply-demand relationship in the future. These include overexploitation of water resources through degradation of watersheds, unchecked extraction of groundwater, rapid pollution brought about by industrialization, saltwater intrusion along coastal areas, and sedimentation of reservoirs (Sosa 1996).

\subsection{Identification of adaptation options}

When addressing adaptation in the water resources sector, adaptations can be divided into 2 major classes: supply adaptation and demand adaptation (Benioff 1996).

Vulnerability analysis showed that the 2 reservoirs are highly susceptible to the expected climate change. With its sensitivity to rainfall changes, runoff for both pilot areas could be dramatically altered with changes in rainfall, both in time and space. The country's water resources sector, including the 2 pilot areas, is highly susceptible to extreme climatic events, like droughts and floods. It would therefore be sensible to identify possible adaptation measures in both the short and long term to cope with the expected global warming and its consequences.

\subsubsection{Supply adaptation}

(1) Comprehensive watershed management. One major concern with respect to the water resources sector is the considerable decline of watersheds. Excessive logging and shifting cultivation in the watersheds trigger widespread degradation and consequent erosion and siltation of rivers, lakes, and reservoirs (Santos 1997). The Angat and Lake Lanao watershed areas face this kind of problem in the future.

Watershed management programs of the government aimed at rehabilitating watershed areas are key steps in preventing degradation of the country's existing watersheds. Both concerned government and private entities should also undertake strict implementation of existing forestry rules and regulations.

(2) Water allocation system and procedures. Water allocation is a powerful tool for managing the demand for water. In the Angat Reservoir, irrigation and hydropower have priority over domestic water supply under normal, non-emergency conditions. However, in times of drought or emergency, domestic water supply gets priority over all others within the limits of its water rights (National Water Resources Board 1976). Con- flicts arise when the M WSS withdraws water from the reservoir over and above its existing water rights, in the process expropriating a portion of the NIA's water rights. Several studies are now being conducted that will provide recommendations on water reallocation and compensation schemes that would meet the demand of the sectors drawing from the Angat Reservoir, particularly in the event of drought or floods in the future.

\subsubsection{Demand adaptation}

(1) Enhancement of irrigation efficiency. As the greatest overall consumer of water, the agricultural sector should strive to increase its efficiency in water use, so that water saved could be used for other purposes. The main problem in the irrigation subsector is low water use efficiency due to technical and institutional deficiencies-flooding in the wet season and inadequate water availability during the dry season. The dilapidated state of canal structures in the systems and the low water use efficiencies result in water loss that goes back to the stream draining the system. Some of the possible responses to enhance irrigation efficiency in the NIA systems are changing the cropping schedule to reduce the demand for irrigation at the end of the dry season and lining canals to reduce water Iosses. In addition, the NIA's program to maximize the use of available water also includes the construction of reservoir-type projects and redesigning of irrigation facilities to reuse return flows.

(2) Introduction of low water use crops and efficient farming practices. The majority of the farm areas that rely on the Angat Reservoir for irrigation needs are planted with rice. Because this crop needs substantial amounts of water from land preparation to its reproductive stage, most of the water coming out of Angat is used by the agricultural sector. During times of drought, the supply of water from the Angat Reservoir is not sufficient to irrigate a substantial portion of these farmlands. The need to look for alternative crops that use less water is then imperative. With the necessary support and assistance from the Department of Agriculture, introduction of such crops can be started.

Use of drip irrigation, mulching, and other improved irrigation practices and the use of windbreaks to reduce windspeed and evapotranspiration are some farming practices that could be adapted (Baradas \& Mina 1996).

(3) Recycling (reuse) of water. Due to recurrent shortages of water, the policy of the government is to encourage reuse of effluent in agriculture and industry. Industries are encouraged to save water and adopt measures to reuse their effluents for other secondary 
purposes. In the case of irrigation systems, drainage water reuse is another possibility for extending the supply of water. The NIA and the farmers are now installing drainage reuse systems to supply water to areas that cannot be reached through the normal irrigation channels.

Water used for power generation, as in multipurpose dams in the 2 pilot areas, is rechanneled for domestic use and irrigation. Households are likewise encouraged to reuse laundry water for flushing and cleaning toilets and driveways during serious water shortages.

(4) Improvement of monitoring and forecasting systems for floods and droughts. One adaptation measure that would be more cost effective and would encounter fewer constraints relative to other adaptation measures is the improvement of the drought/ flood monitoring and forecasting capability. It has been shown that droughts and floods have tremendous effects on water resources, and climate change is likely to affect the frequency of droughts and floods. Improvement of the present system of knowing in advance future occurrences of such events could be translated into improved water management. It is worthwhile to mention that monitoring systems will help in coping with these changes and would still be beneficial even without climate change.

(5) Use of water pricing policies and structures. Water has traditionally been treated as a public good, and the government is expected to bear the cost of making this commodity accessible to the population. With the growing scarcity of water, especially in M etro Manila, and the constraints on financial resources, there is now an increasing tendency to shift to a commodity focus in which water users bear the full cost of being supplied with water.

\section{CONCLUSION}

The expected climate changes that could affect rainfall distribution will ultimately affect runoff to rivers and lakes. Based on runoff simulation results, the expected rise in temperature in the future may not be a significant factor in runoff variability. However, there is a need for further study on this aspect. The resulting local warming with a corresponding decrease in runoff could have adverse consequences on the water demand side. This problem could be aggravated by the increasing population translated into more demand for water and degradation of the physical environment that could possibly affect, to a certain extent, the hydrology of the area.

Both pilot areas as shown by historical data have experienced large increases or decreases in rainfall in the past. This leads to a conclusion that the Angat Reservoir and Lake Lanao, which are already exposed to extreme rainfall variability and its adverse consequences, face more threats of increased climatic variabilities as suggested by results of selected GCMs.

This study, being the first of its kind to have been undertaken for both Angat and Lake Lanao, should be expanded. Further research is recommended for other existing major reservoirs. The effects of climate change on other meteorological variables should also be investigated because this assessment presumes that changes in temperature and rainfall would not affect other parameters such as humidity, wind speed, and related variables. The effect of climate change on future water demand (agriculture, industry, domestic) as well as impacts of non-climatic variables such as population increase, land use activities, and pollution should al so be studied. There are still a number of limitations that have to be resolved in order to come up with a comprehensive assessment of how climate change would affect the country's future water resources.

Adaptation measures identified could still be refined further. Participation of the various stakeholders will be of utmost significance in the realization of such schemes. It is also hoped that future government policies and long-term development plans incorporate potential impacts of climate change.

Acknowledgements. The authors are indebted to the Philippine Country Study on Climate Change and the US Country Study Team for providing the necessary financial and technical support. The authors also wish to extend their heartfelt gratitude to the members of the Angat and the Lake Lanao Study Teams.

\section{LITERATURE CITED}

Baradas M W, Mina J G (1996) Water management 2000: not by irrigation alone. Presented at Workshop on Food Security, Los Baños, Laguna

Benioff R (1996) Guidance for vulnerability and adaptation assessments. Version 1.0. US Country Studies Program, Washington, DC

Boer GJ, M cFarlane NA, Lazare M (1992) Greenhouse gasinduced climatic change simulated with the CCC secondgeneration general circulation model. J Climatol 5: 1045-1077

IPCC (Intergovernmental Panel on Climate Change) (1996a) Climate change 1995: the IPCC second assessment report, Vol 2: scientific-technical analyses of impacts. A daptations and mitigation of climate change. Watson RT, Zinyowera MC, Moss RH (eds). Cambridge University Press, Cambridge

IPCC (1996b) Climate change 1995: the science of climate change, summary for policymakers and technical summary of the Working Group I report. Cambridge University Press, Cambridge 
IPCC (1996c) Climate change 1995: impacts, adaptations and mitigation of climate change, scientific-technical analyses. Contribution of Working Group II to the second assessment report of the Intergovernmental Panel on Climate Change. Cambridge University Press, Cambridge

J ose AM (1992) Preliminary assessment of the 1991-1992 ENSO-related drought event in the Philippines. PAGASA, Quezon City

J ose AM, Francisco RV, Cruz NA (1993) A preliminary study on the impact of climate variability/change on water resources in the Philippines. PAGASA, Quezon City

J ose AM, Sosa LM, Cruz NA (1996) Vulnerability assessment of Angat water reservoir to climate change. PAGASA, Quezon City

Manabe S, Wetherald RT (1987) Large scale changes in soil wetness induced by an increase in carbon dioxide. J Atmos Sci 44:1211-1235

National Irrigation Administration (NIA) (1997) Report to the Philippine country study to address climate change. NIA, Quezon City

National Power Corporation (NPC)-Iligan (1997) Report to the Philippine country study to address climate change.
NPC, Iligan City

National Water Resources Board (NWRB) (1976) Water code of the Philippines and implementing rules and regulations. NWRB, Quezon City

Rosacay DA (1989) Angat Dam level management and hydro forecasting. Technical paper presented on First Workshop Operation and Control Issues. ASEAN Cooperation Project No. 3. NPC, Quezon City

Santos DA (1997) Overview of the integrated watershed management and development in the Philippines. Paper presented in the briefing of Indonesian nationals. NIA, FMB, Quezon City

Sosa LM (1996) Water and sustainable development in the Philippines. Presented at International Conference and Exhibition on Water Resources Management. NWRB, Quezon City

Wilson CA, M itchell J FB (1987) A doubled $\mathrm{CO}_{2}$ climate sensitivity experiment with a global climate model including a simple ocean. J Geophys Res 92(D11):13315-13343

Yates D (1994) WatBal - an integrated water balance model for climate impact assessment of river basin runoff. IIASA Working Paper WP-94-64, Laxenburg 